\title{
PEMBERIAN PUPUK KANDANG DAN UREA PADA BIBIT TANAMAN MAHONI (Switenia macrophylla King)
}

\author{
Azwin \\ Staf Pengajar Fakultas Kehutanan Universitas Lancang Kuning, \\ Jln. Yos Sudarso Km.8 Rumbai, Pekanbaru, Riau, Telp/Fax (0761) 54092 \\ Email: azwin@unilak.ac.id
}

\begin{abstract}
This study aimed to get a dose of manure and urea appropriate, as well as a good combination on the growth of seedling mahoni (S. macrophylla King). Research conducted an experiment using a completely randomized design (CRD) 2 factors, factors chicken manure ( $k$ ) consists of four levels i.e. $k 0$ (without manure), $k 1$ (manure, $200 \mathrm{~g} /$ seeds), $\mathrm{k} 2$ (manure, $400 \mathrm{~g} / \mathrm{seed}$ ) and $\mathrm{k3}$ (manure, $600 \mathrm{~g} / \mathrm{seed}$ ) and factor Urea (n) consists of four levels i.e. no (without urea), n1 (Urea $2.5 \mathrm{~g} /$ seeds), n2 (Urea $5 \mathrm{~g} / \mathrm{seed}$ ) and $\mathrm{n} 3$ (Urea $7.5 \mathrm{~g} / \mathrm{seeds}$ ), each replicated three times. Results of analysis of variance on a test level of 0.05 indicates that Manure significantly affected parameters plant height and number of lateral roots, while the stem diameter, number of leaves and length of main root effect is not real, the best treatment contained in $\mathrm{k} 3$ (manure $600 \mathrm{~g} / \mathrm{seed}$ ). Further provision of urea no real effect on all parameters was observed, while the combination of manure and urea real effect only on the parameters of the main root length and number of lateral roots is the best dose at $600 \mathrm{~g} /$ plant manure and $7.5 \mathrm{~g} /$ seedling urea. In parameter plant height, stem diameter and number of leaves no real effect.
\end{abstract}

Keywords: Mahoni, Manure, Urea

\section{PENDAHULUAN}

Mahoni (Swietenia macrophylla King) merupakan tanaman yang baik untuk dibudidayakan karena kualitas kayunya baik untuk dijadikan perabot rumah tangga, meubel dan juga baik untuk konstruksi bangunan, sedangkan minyak dan bijinya bernilai ekonomis, pepaganya untuk bahan pewarna dan penyamak, sedangkan bijinya dapat dipergunakan sebagai bahan campuran pembuat obat malaria (Sutisna, 1998).

Dewasa ini mahoni merupakan tanaman kayuan yang berpotensi untuk dikembangkan sebagai tanaman hutan yang bernilai komersil. Upaya untuk pengembangan tanaman ini diperlukan bibit berkualitas, yaitu dengan cara pengadaan bibit melalui penelitian di pembibitan sebagai upaya untuk keberhasilan penanaman di lapangan. 
Perbanyakan tanaman mahoni bisa dilakukan secara vegetatif maupun secara generatif. Secara vegetatif bisa menggunakan stek pucuk dan kultur jaringan, sedangkan secara generatif menggunakan biji dan anakan cabutan dari alam.

Kabupaten Kampar merupakan bagian dari wilayah Riau dan Indonesia yang termasuk daerah tropis dengan kondisi hutan sudah banyak berubah fungsi menjadi areal perkebunan baik sawit maupun karet. Untuk menjaga agar tetap terjadinya keseimbangan ekosistim alam maka mau tidak mau semua kalangan harus memulai dengan kesadarannya untuk menanam kayukayuan baik di kebun, pekarangan bahkan juga di areal tanaman sawit dan karet, di jalan-jalan dan di pinggiran sungai. Untuk menunjang terlaksananya kegiatan gerakan penanaman, salah satunya adalah harus terpenuhinya bibit tanaman kayu-kayuan yang sehat, bermutu, vigor baik, cocok di daerah tempatan, cepat tumbuh dan bernilai ekonomis dan didasari akan pemulihan kelestarian fungsi hutan.

Kabupaten Kampar dengan jenis tanah Podzolik Merah Kuning (PMK) yang salah satunya ditandai miskin unsur hara, maka untuk mengatasi hal tersebut maka perlakuan pemberian unsur hara melalui pemberian pupuk kandang dan urea merupakan hal yang baik dalam rangka penambahan unsur hara dan memacu pertumbuhan bibit mahoni. Jika dibandingkan dengan pupuk anorganik maka pupuk kandang (organik) mempunyai kelebihan karena selain sifatnya dapat memperbaiki struktur tanah, memiliki unsur hara esensial yang lebih lengkap, namun kadarnya lebih rendah. Sedangkan urea berfungsi mempercepat pertumbuhan tanaman bibit muda dan berguna menambah unsur hara dalam tanah yang sangat dibutuhkan untuk kehidupan tanaman.

Berdasarkan permasalahan di atas, maka penulis tertarik untuk melakukan penelitian dengan judul "Pemberian Pupuk Kandang dan Urea Pada Bibit Tanaman Mahon (Swietenia macrophyilla King)". Penelitian ini bertujuan untuk mendapatkan dosis pupuk kandang dan urea yang tepat, serta kombinasi keduanya yang baik terhadap pertumbuhan bibit Mahoni (Swietenia macrophylla King).

\section{BAHAN DAN METODE Tempat dan Waktu.}

Penelitian ini dilaksanakan di Kebun PKK Kabupaten Kampar Jl. Letnan Boyak No. 07 Bangkinang yang 
terletak pada ketinggian lokasi 40 meter dari permukaan laut dengan suhu antara $23^{\circ} \mathrm{C}-33^{\circ} \mathrm{C}$, jenis tanah PMK. Penelitian dilaksanakan bulan Oktober 2011 sampai Januari 2012.

\section{Bahan dan Alat}

Bahan yang digunakan adalah bibit Mahoni berumur 2 (dua) bulan, Pupuk Kandang ayam, Pupuk Urea, Thiodan 35 EC, Dithane M-45, paku, seng, polybag ukuran $15 \mathrm{~cm} \times 30 \mathrm{~cm}$ dan tali nilon. Alatalat yang digunakan adalah cangkul, parang, meteran, jangka sorong, timbangan, hands sprayer, martil, dan alat-alat tulis lainnya.

\section{Metode Penelitian}

Penelitian ini dilakukan secara eksperimen dengan menggunakan Rancangan Acak Lengkap (RAL) 2 (dua) faktor yaitu faktor pupuk kandang ayam (k) terdiri dan 4 taraf dan faktor pupuk Urea (n) terdiri dari 4 taraf, masingmasing diulang 3 kali, sehingga diperoleh 16 kombinasi perlakuan dan 48 satuan percobaan. Setiap satuan percobaan terdiri dari 3 tanaman dan 2 tanaman sebagai sampel.

Faktor pupuk kandang terdiri dari 4 taraf yaitu: $\mathrm{k}_{0}=$ Tanpa pemberian pupuk kandang, $\mathrm{k}_{1}=$ Pemberian pupuk kandang, 200 gram/bibit, k2 = Pemberian pupuk kandang, $400 \mathrm{gram} / \mathrm{bibit}, \mathrm{k}_{3}=$ Pemberian pupuk kandang, 600 gram/bibit. Faktor pupuk urea terdiri dari 4 taraf yaitu: $n_{0}=$ Tanpa pemberian pupuk Urea, $\mathrm{n}_{1}=$ Pemberian pupuk Urea 2,5 g/bibit, $\mathrm{n}_{2}=$ Pemberian pupuk Urea 5 $\mathrm{g} /$ bibit, $\mathrm{n}_{3}=$ Pemberian pupuk Urea 7,5 g/bibit

Model Matematika Rancangan Acak Lengkap (RAL) (Hanafiah, 2003):

$$
Y i j k=\mu+k i+n j+(k n) i j+\varepsilon i j k
$$

Data yang diperoleh dari hasil pengamatan dianalisa dengan menggunakan sidik ragam. Selanjutnya apabila $F$ hitung $\geq F$ tabel, maka dilakukan uji lanjut dengan DMRT pada taraf $5 \%$.

\section{Pelaksanaan Penelitian.}

a. Persiapan areal dan Media Tanam

Lahan berukuran $8 \times 14 \mathrm{~m}$ dibersihkan dari semua gulma dan kotoran yang mengganggu. Selanjutnya dibuat plot ukuran $100 \times 100 \mathrm{~cm}$. Jarak antar plot dan dalam plot $50 \mathrm{~cm}$. Lokasi dipagar keliling minimal $1 \mathrm{~m}$ dari tepi barisan plot. Media yang digunakan dalam polybag adalah top soil yang sudah dibersihkan dari kotoran dan dikeringanginkan. Untuk setiap polybag diisi $5 \mathrm{~kg}$ media. Polybag yang telah diisi 
disusun menurut tata letak penempatan plot di lapangan.

b. Pemasangan Label dan Seleksi Bibit

Label terbuat dari seng plat berukuran $10 \times 15 \mathrm{~cm}$, dipasangkan di setiap satuan percobaan sesuai letak satuan plot pada bagan penelitian. Bibit Mahoni yang dipergunakan merupakan basil seleksi di persemaian dengan kriteria sehat, tinggi bibit dan jumlah daun yang sama serta berumur 2 bulan.

\section{c. Pemberian Perlakuan}

Pupuk kandang dengan dosis sesuai perlakuan dicampurkan dengan media dan diberikan seminggu sebelum penanaman bibit. Pupuk Urea diberikan seminggu setelah bibit ditanam di polybag dengan cara membenamkan ke dalam media dengan jarak minimal 10 $\mathrm{cm}$ dari pangkal batang sedalam $5 \mathrm{~cm}$ dengan dosis sesuai perlakuan, diberikan sekali selama penelitian.

d. Penanaman

Penanman dilakukan dengan memindahkan bibit prenurseri (dalam polybag), dari persemaian yang telah diseleksi dengan cara merobek dengan pisau agar polybag terlepas dari bibit. Agar media tetap padat/tidak mudah pecah lakukan penyiraman terlebih dahulu. Setelah itu bibit ditanamkan di polybag sampai batas leher akar.

\section{e. Pemeliharaan}

Penyiraman dilakukan 2 kali sehari pagi dan sore, dengan menggunakan gembor. Jika turun hujan dan kondisi tanah basah pada kapasitas lapang maka tidak di lakukan penyiraman. Penyiangan dilakukan secara manual apabila terdapat gulma yang tumbuh di dalam polybag, yaitu dengan cara mencabut. Pengendalian hama dan penyakit dilakukan sebagai tindakan preventif dengan menyemprotkan Thiodan 35 EC dan Dithane masingmasing dengan dosis $1 \mathrm{cc} / \mathrm{l}$ air dan $1 \mathrm{~g} / \mathrm{l}$ air setiap 15 hari sekali, dimulai 1 minggu setelah tanaman sampai akhir penelitian.

\section{Pengamatan.}

Pengamatan dilakukan pada akhir penelitian, adapun parameter yang diamati adalah:

1. Tinggi Tanaman $(\mathrm{cm})$, pengukuran tinggi tanaman dilakukan mulai dari leher akar sampai pada titik tumbuh terakhir dengan menggunakan mistar.

2. Diameter Batang $(\mathrm{mm})$, pengukuran diameter batang dilakukan $5 \mathrm{~cm}$ diatas leher akar, dengan menggunakan jangka sorong.

3. Jumlah Daun (helai) penghitungan jumlah daun dilakukan dengan 
menghitungan jumlah daun yang ada di akhir penelitian.

4. Panjang Akar Utama (cm) pengukuran panjang akar utama dimulai dari leher akar sampai ujung akar utama.

5. Jumlah Akar Lateral (helai) pengukuran jumlah akar lateral, dengan menghitung jumlah akar lateral yang berasal dari akar utama.

\section{HASIL DAN PEMBAHASAN Hasil}

Hasil penelitian pengaruh dosis pupuk kandang dan urea terhadap pertumbuhan tanaman mahoni untuk masing-masing parameter disajikan sebagai berikut:

\section{a. Tinggi Tanaman (cm)}

Hasil pengamatan dan sidik ragam terhadap tinggi tanaman mahoni setelah dianalisis secara statistik berpengaruh nyata untuk faktor pupuk kandang, sedangkan untuk faktor urea dan interaksi pupuk kandang dan urea tidak berpengaruh nyata, sedangkan rerata tinggi tanaman mahoni dan uji lanjut DMRT 5\% dapat dilihat pada Tabel 1.

Tabel 1. Rata-Rata Tinggi Tanaman Mahoni (cm) yang Diberi Perlakuan Pupuk Kandang dan Urea

\begin{tabular}{|c|c|c|c|c|c|}
\hline \multirow{2}{*}{$\begin{array}{l}\text { Faktor Pupuk } \\
\text { Kandang (k) }\end{array}$} & \multicolumn{4}{|c|}{ Faktor Urea $(\mathrm{n})$} & \multirow{2}{*}{ Rerata k } \\
\hline & $\mathrm{n}_{0}(0)$ & $\mathrm{n}_{1}(2,5)$ & $\mathrm{n}_{2}(5)$ & $\mathrm{n}_{3}(7,5)$ & \\
\hline ko (0) & 35,30 & 36,00 & 35,30 & 38,67 & $36,33 \mathrm{a}$ \\
\hline$k_{1}(200)$ & 37,30 & 38,00 & 38,67 & 39,67 & $38,58 \mathrm{a}$ \\
\hline $\mathrm{k}_{2}(400)$ & 38,67 & 39,00 & 39,30 & 38,30 & $38,83 \mathrm{a}$ \\
\hline $\mathrm{k}_{3}(600)$ & 38,30 & 39,30 & 39,00 & 43,30 & $40,00 \mathrm{~b}$ \\
\hline Rerata $n$ & 37,42 & 38,08 & 38,25 & 40,00 & \\
\hline
\end{tabular}

Tabel 1 menunjukkan bahwa pemberian pupuk kandang pada beberapa dosis yang berbeda dapat menambah tinggi tanaman mahoni, semakin tinggi dosis pupuk kandang yang diberikan semakin tinggi tanaman mahoni. Pada pemberian dosis pupuk kandang $600 \mathrm{~g} /$ tanaman memberikan pengaruh yang paling baik terhadap tinggi tanaman mahoni yaitu $40 \mathrm{~cm}$.
Sedangkan perlakuan dengan menggunakan pupuk urea menunjukkan bahwa semua perlakuan $\mathrm{n}_{0}, \mathrm{n}_{1}, \mathrm{n}_{2}$ dan $\mathrm{n}_{3}$, menunjukkan berbeda tidak nyata terhadap tinggi tanaman mahoni. Penggunaan pupuk kandang dan urea secara bersamaan pada parameter tinggi tanaman menunjukkan pengaruh tidak nyata pada berbagai dosis yang diberikan. 


\section{b. Diameter Batang ( $\mathrm{mm}$ )}

Hasil pengamatan dan sidik ragam terhadap diameter batang tanaman mahoni setelah dianalisis secara statistik berpengaruh tidak nyata untuk faktor pupuk kandang dan faktor urea begitu juga interaksi pupuk kandang dan urea berpengaruh tidak nyata, sedangkan rerata diameter batang tanaman mahoni dan uji lanjut DMRT 5\% dapat dilihat pada Tabel 2.

Tabel 2. Rata-Rata Diameter Batang $(\mathrm{mm})$ Mahoni yang Diberi Perlakuan Pupuk Kandang dan Urea

\begin{tabular}{cccccc}
\hline Faktor Pupuk & \multicolumn{4}{c}{ Faktor Urea $(\mathrm{n})$} & \multirow{2}{*}{ Rerata k } \\
\cline { 2 - 4 } Kandang $(\mathrm{k})$ & $\mathrm{n}_{0}(0)$ & $\mathrm{n}_{1}(2,5)$ & $\mathrm{n}_{2}(5)$ & $\mathrm{n}_{3}(7,5)$ & \\
\hline $\mathrm{k}_{0}(0)$ & 7,00 & 7,30 & 7,00 & 7,00 & 7,00 \\
$\mathrm{k}_{1}(200)$ & 7,67 & 7,67 & 7,30 & 8,00 & 7,08 \\
$\mathrm{k}_{2}(400)$ & 7,33 & 7,33 & 9,00 & 7,30 & 7,50 \\
k $_{3}(600)$ & 7,00 & 7,00 & 6,30 & 7,67 & 7,92 \\
Rerata $\mathrm{n}$ & 7,25 & 7,33 & 7,42 & 7,50 & \\
\hline
\end{tabular}

Tabel 2 adalah rata-rata diameter batang mahoni yang diberi perlakuan pupuk kandang dan urea. Hasil sidik ragam menunjukkan bahwa perlakuan pemberian pupuk kandang dan urea secara tunggal maupun kombinasi (interaksi) berpengaruh tidak nyata terhadap diameter batang mahoni.

\section{c. Jumlah Daun (helai)}

Hasil pengamatan dan sidik ragam terhadap jumlah daun tanaman mahoni setelah dianalisis secara statistik berpengaruh tidak nyata untuk faktor pupuk kandang dan faktor urea begitu juga interaksi pupuk kandang dan urea berpengaruh tidak nyata, sedangkan rerata jumlah daun tanaman mahoni dan uji lanjut DMRT 5\% dapat dilihat pada Tabel 3.

Tabel 3. Rata-Rata Jumlah Daun (helai) Mahoni yang Diberi Perlakuan Pupuk Kandang dan Urea

\begin{tabular}{|c|c|c|c|c|c|}
\hline \multirow{2}{*}{$\begin{array}{c}\text { Faktor Pupuk } \\
\text { Kandang (k) }\end{array}$} & \multicolumn{4}{|c|}{ Faktor Urea $(n)$} & \multirow{2}{*}{ Rerata k } \\
\hline & $\mathrm{n}_{0}(0)$ & $\mathrm{n}_{1}(2,5)$ & $\mathrm{n}_{2}(5)$ & $n_{3}(7,5)$ & \\
\hline $\mathrm{k}_{0}(0)$ & 12,67 & 13,30 & 13,30 & 14,67 & 13,50 \\
\hline $\mathrm{k}_{1}(200)$ & 13,00 & 15,00 & 14,00 & 14,30 & 14,08 \\
\hline $\mathrm{k}_{2}(400)$ & 14,00 & 15,00 & 14,00 & 13,67 & 14,17 \\
\hline $\mathrm{k}_{3}(600)$ & 14,00 & 15,00 & 15,00 & 14,67 & 14,67 \\
\hline Rerata n & 13,92 & 14,08 & 14,08 & 14,33 & \\
\hline
\end{tabular}

Tabel 3 adalah rata-rata jumlah pupuk kandang dan urea. Hasil sidik daun mahoni yang diberi perlakuan ragam menunjukkan bahwa perlakuan 
pemberian pupuk kandang dan urea secara tunggal maupun kombinasi (interaksi) pada berbagai dosis

Hasil pengamatan dan sidik ragam terhadap panjang akar utama tanaman mahoni setelah dianalisis secara statistik berpengaruh tidak nyata untuk faktor pupuk kandang dan faktor urea, tetapi berpengaruh tidak nyata terhadap jumlah daun mahoni.

\section{d. Panjang Akar Utama (cm)}

interaksi pupuk kandang dan urea berpengaruh nyata, sedangkan rerata panjang akar utama tanaman mahoni dan uji lanjut DMRT 5\% dapat dilihat pada Tabel4.

Tabel 4. Rata-Rata Panjang Akar Utama (cm) Mahoni yang Diberi Perlakuan Pupuk Kandang dan Urea

\begin{tabular}{cccccc}
\hline Faktor Pupuk & \multicolumn{4}{c}{ Faktor Urea $(\mathrm{n})$} & \multirow{2}{*}{ Rerata $\mathrm{k}$} \\
\cline { 2 - 4 } Kandang $(\mathrm{k})$ & $\mathrm{n}_{0}(0)$ & $\mathrm{n}_{1}(2,5)$ & $\mathrm{n}_{2}(5)$ & $\mathrm{n}_{3}(7,5)$ & \\
\hline $\mathrm{k}_{0}(0)$ & $20,43 \mathrm{aA}$ & $21,37 \mathrm{aA}$ & $18,27 \mathrm{aA}$ & $15,50 \mathrm{aA}$ & 18,89 \\
$\mathrm{k}_{1}(200)$ & $20,50 \mathrm{abA}$ & $21,63 \mathrm{abA}$ & $23,97 \mathrm{bA}$ & $15,83 \mathrm{aA}$ & 20,48 \\
$\mathrm{k}_{2}(400)$ & $15,97 \mathrm{aA}$ & $16,93 \mathrm{aA}$ & $24,20 \mathrm{bA}$ & $25,03 \mathrm{bB}$ & 20,53 \\
$\mathrm{k}_{3}(600)$ & $16,97 \mathrm{aA}$ & $23,57 \mathrm{aA}$ & $22,47 \mathrm{aA}$ & $23,53 \mathrm{aB}$ & 21,63 \\
Rerata $\mathrm{n}$ & 18,47 & 19,98 & 20,88 & 22,23 & \\
\hline
\end{tabular}

Angka-angka pada baris dan kolom yang diikuti oleh huruf kecil dan huruf besar yang sama menunjukkan berbeda tidak nyata pada uji lanjut DMRT 5\%.

Tabel 4 adalah rata-rata panjang akar utama tanaman mahoni yang diberi perlakuan pupuk kandang dan urea. Hasil sidik ragam menunjukkan bahwa perlakuan pupuk kadang dan urea secara tunggal dengan berbagai dosis berpengaruh tidak nyata terhadap panjang akar utama mahoni, tetapi pemberian secara bersamaan (interaksi) menunjukkan berbeda nyata pada panjang akar utama mahoni.

\section{e. Jumlah Akar Lateral (helai)}

Hasil pengamatan dan sidik ragam terhadap jumlah akar lateral setelah dianalisis secara statistik berpengaruh nyata untuk faktor pupuk kandang, sedangkan untuk faktor urea dan interaksi pupuk kandang dan urea berpengaruh tidak nyata, sedangkan rata-rata jumlah akar lateral dan uji lanjut DMRT 5\% dapat dilihat pada Tabel 5.

Tabel 5. Rata-Rata Jumlah Akar Lateral (helai) Mahoni yang Diberi Perlakuan Pupuk Kandang dan Urea

\begin{tabular}{cccccc}
\hline \multirow{2}{*}{$\begin{array}{c}\text { Faktor Pupuk } \\
\text { Kandang }(\mathrm{k})\end{array}$} & \multicolumn{4}{c}{ Faktor Urea $(\mathrm{n})$} & \multirow{2}{*}{ Rerata k } \\
\cline { 2 - 5 } & $\mathrm{n}_{0}(0)$ & $\mathrm{n}_{1}(2,5)$ & $\mathrm{n}_{2}(5)$ & $\mathrm{n}_{3}(7,5)$ & \\
\hline $\mathrm{k}_{0}(0)$ & $8,67 \mathrm{bcA}$ & $7,33 \mathrm{abA}$ & $6,33 \mathrm{aA}$ & $9,67 \mathrm{cBC}$ & $8,00 \mathrm{a}$ \\
\hline
\end{tabular}




\begin{tabular}{cccccc}
\hline \multirow{2}{*}{$\begin{array}{c}\text { Faktor Pupuk } \\
\text { Kandang }(\mathrm{k})\end{array}$} & \multicolumn{4}{c}{ Faktor Urea $(\mathrm{n})$} & \multirow{2}{*}{ Rerata $\mathrm{n}$} \\
\cline { 2 - 5 } & $\mathrm{n}_{0}(0)$ & $\mathrm{n}_{1}(2,5)$ & $\mathrm{n}_{2}(5)$ & $\mathrm{n}_{3}(7,5)$ & \\
\hline $\mathrm{k}_{1}(200)$ & $8,00 \mathrm{abA}$ & $9,00 \mathrm{bB}$ & $8,33 \mathrm{abA}$ & $7,00 \mathrm{aA}$ & $8,08 \mathrm{a}$ \\
$\mathrm{k}_{2}(400)$ & $10,33 \mathrm{bB}$ & $7,33 \mathrm{aA}$ & $8,33 \mathrm{aA}$ & $8,67 \mathrm{aB}$ & $8,67 \mathrm{a}$ \\
$\mathrm{k}_{3}(600)$ & $7,67 \mathrm{aA}$ & $9,33 \mathrm{bB}$ & $11,67 \mathrm{cB}$ & $10,67 \mathrm{bcC}$ & $9,83 \mathrm{~b}$ \\
Rerata $\mathrm{n}$ & 8,25 & 8,67 & 8,67 & 9,00 & \\
\hline
\end{tabular}

Angka-angka pada kolom yang diikuti oleh huruf kecil yang sama menunjukkan berbeda tidak nyata pada uji lanjut DMRT $5 \%$.

Tabel 5 menunjukkan bahwa pemberian pupuk kandang pada beberapa dosis yang berbeda dapat menambah jumlah akar lateral tanaman mahoni, semakin tinggi dosis pupuk kandang yang diberikan semakin jumlah akar lateral tanaman mahoni. Pada pemberian dosis pupuk kandang 600 g/tanaman memberikan pengaruh yang paling baik/nyata terhadap jumlah akar lateral tanaman mahoni yaitu $9,83 \mathrm{~cm}$. Sedangkan pemberian pupuk urea pada beberapa dosis berpengaruh tidak nyata. Interaksi penggunaan pupuk kandang dan urea memberinkan pengaruh nyata pada jumlah akar lateral tanaman mahoni.

\section{Pembahasan}

\section{a. Pengaruh Pupuk Kandang}

Berdasarkan hasil sidik ragam pada taraf $5 \%$ terlihat bahwa perlakuan pupuk kandang berpengaruh nyata terhadap pertumbuhan tanaman mahoni pada parameter yang diamati yaitu tinggi tanaman dan jumlah akar lateral, sedangkan pada parameter diameter batang, jumlah daun dan panjang akar utama berpengaruh tidak nyata.

Data hasil pengamatan terlihat bahwa perlakuan ko (tanpa pupuk kandang) menghasilkan pertumbuhan tinggi tanaman mahoni terendah yaitu $36,33 \mathrm{~cm}$ diikuti oleh perlakuan $\mathrm{k}_{1}$, $\mathrm{k}_{2}$ dan k3. Angka pertumbuhan yang tertinggi ditunjukkan oleh perlakuan $\mathrm{k}_{3}$ yaitu 40,00 $\mathrm{cm}$. Pada perlakuan ko tanaman mahoni hanya mendapatkan unsur hara dari media yang digunakan, sehingga untuk pertumbuhan yang baik perlu dilakukan pemupukan dengan dosis yang tepat. Tanah yang miskin akan unsur hara perlu dilakukan pemupukan dengan pupuk organik seperti pupuk kandang, agar tanah menjadi lebih gembur dan subur.

Lingga (1999) menyatakan bahwa tanah yang akan ditanami dengan tanaman dan berproduksi dengan baik, tanah itu harus mempunyai persediaan yang cukup akan unsur hara yang diperlukan oleh tanaman dari dalam tanah. Tidak saja hara yang diperlukan harus tersedia dalam bentuk yang dapat digunakan tanaman, tetapi juga harus 
ada keseimbangan diantara unsur-unsur hara tersebut yang sesuai dengan jumlah yang dibutuhkan tanaman.

Pertumbuhan tanaman terjadi karena adanya proses-proses pembelahan sel dan pemanjangan sel dimana proses-proses tersebut memerlukan karbohidrat dalam jumlah besar. Gardner et al. (1991) menyatakan bahwa pertumbuhan dan hasil suatu tanaman dipengaruhi oleh keadaan lingkungan tumbuhnya. Salah satu faktor lingkungan tumbuh yang penting bagi pertumbuhan tanaman adalah ketersediaan unsur hara dan pengendalian organisme pengganggu tanaman.

Pertumbuhan tanaman, merupakan proses peningkatan jumlah sel, ukuran sel dan deferensiasi sel (Gardner, et.al., 1985). Dikatakan pula bahwa pertumbuhan tanaman dipengaruhi oleh kegiatan meristem tanaman yaitu meristem ujung yang merupakan jaringan-jaringan sel tanaman yang menghasilkan sel-sel baru diujung akar dan bagian tunas, sehingga membentuk tanaman bertambah tinggi dan panjang.

Meningkatnya pertumbuhan tinggi tanaman mahoni sejalan dengan peningkatan dosis pupuk kandang yang diberikan terutama pada dosis $\mathrm{k}_{3}$ yaitu 40 cm. Suryanto dan Suryanto (1981) dalam Junita et al. (2002) menyatakan bahwa semakin banyak bahan organik yang diberikan pada tanah, akan diikuti dengan kenaikan kemantapan tanah mengikat air sampai batas tertentu dan kenaikan nitrogen total.

Kastono (1999) mengemukakan bahwa pemupukan mempunyai dua tujuan utama, yaitu: (1) mengisi perbekalan zat makanan tanaman yang cukup, dan (2) memperbaiki atau memelihara keutuhan kondisi tanah, dalam hal struktur, kondisi $\mathrm{pH}$, potensi pengikat terhadap zat makanan tanaman dan sebagainya. Guna mencapai tujuan di atas pemupukan harus mengikuti prinsip enam tepat, yaitu: tepat jumlah, jenis, cara, tempat, waktu, dan disesuaikan dengan sifat/jenis tanah

Berdasarkan dari data yang diperoleh dalam penelitian ini menunjukkan bahwa pada parameter diameter batang, jumlah daun, panjang akar utama dan jumlah akar lateral menunjukkan bahwa perlakuan $\mathrm{k}_{3}$ menghasilkan angka tertinggi yaitu berturut-turut 7,92 cm, 14,67 helai daun, $21,63 \mathrm{~cm}$ dan 9,83 helai akar, meskipun dari hasil analisis sidik ragam menunjukkan berpengaruh tidak nyata. Kecuali pada parameter jumlah akar 
lateral dan tinggi tanaman, hal ini mengindikasikan bahwa pada dosis tersebut kebutuhan unsur hara untuk pertumbuhan mahoni sudah cukup. Karena pupuk kadang dapat memperbaiki sifat fisik, kimia dan biologi tanah. Sifat fisik tanah yang keras dengan pemberian pupuk kandang, maka tanah menjadi gembur dan remah, sifat kimia tanah artinya pupuk kandang dapat menambah unsur hara sedangkan sifat biologi dapat meningkatkan kandungan jasad renik dalam tanah yang berfungsi sebagai dekomposer.

Menurut Sutanto (2002) bahwa pupuk kandang memiliki sifat yang alami dan tidak merusak tanah, menyediakan unsur makro (nitrogen, fosfor, kalium, kalsium, dan belerang) dan mikro (besi, seng, boron, kobalt, dan molibdenium). Selain itu pupuk kandang berfungsi untuk meningkatkan daya menahan air, aktivitas mikrobiologi tanah, nilai kapasitas tukar kation dan memperbaiki struktur tanah. Sehingga akar-akar tanaman lebih mudah menembus tanah untuk mendapatkan unsur hara.

Pemberian pupuk kandang selain dapat menambah tersedianya unsur hara, juga dapat memperbaiki sifat fisik tanah. Beberapa sifat fisik tanah yang dapat dipengaruhi pupuk kandang antara lain kemantapan agregat, bobot volume, total ruang pori, plastisitas dan daya pegang air (Soepardi dalam Mahadewi, 1995).

\section{b. Pengaruh Urea}

Berdasarkan hasil sidik ragam pada taraf $5 \%$ terlihat bahwa perlakuan pupuk urea berpengaruh tidak nyata terhadap pertumbuhan tanaman mahoni pada semua parameter yang diamati yaitu tinggi tanaman, diameter batang, jumlah daun, panjang akar utama dan jumlah akar lateral.

Data hasil pengamatan terlihat bahwa perlakuan no menghasilkan pertumbuhan mahoni terendah yaitu berturut-turut 36,$33 ; 7,00 ; 13,50 ; 18,89$; dan 8,00 pada semua parameter yang diamati, dibandingkan perlakuan lainnya. Hal ini disebabkan karena tanaman mahoni hanya mendapatkan unsur hara dari media yang digunakan, sehingga untuk pertumbuhan yang baik perlu dilakukan pemupukan dengan dosis yang tepat. Tanah PMK yang miskin akan unsur hara perlu dilakukan pemupukan dengan pupuk anorganik seperti urea, agar tanah dapat menyediakan unsur hara yang cukup untuk pertumbuhan mahoni. 
Lindawati et al. (2000), menyatakan pupuk nitrogen (urea) merupakan pupuk yang sangat penting bagi semua tanaman, karena nitrogen merupakan penyusun dari semua senyawa protein, kekurangan nitrogen pada tanaman yang sering dipangkas akan mempengaruhi pembentukkan cadangan makanan untuk pertumbuhan tanaman.

Berdasarkan dari data yang diperoleh dalam penelitian ini menunjukkan bahwa pertumbuhan dan produksi yang terbaik dari semua perlakuan yang dicoba diperlihatkan oleh perlakuan $\mathrm{n}_{3}$. Hal ini diduga karena pemberian pupuk urea pada dosis tersebut sudah cukup untuk dapat dimanfaatkan oleh tanaman mahoni untuk pertumbuhannya. Pupuk urea mengandung unsur hara $\mathrm{N}$ dalam kadar yang cukup tinggi (46\%), yang berperan dalam berbagi persenyawaan dalam tubuh tumbuhan. Unsur $\mathrm{N}$ merupakan komponen penyusun dari banyak senyawa esensial seperti asam amino dan juga terkandung dalam khlorofil yang berfungsi dalam pembentukan pertumbuhan bagian-bagian vegetatif tanaman, seperti batang, daun dan akar. Apabila pemberian pupuk $\mathrm{N}$ terlalu sedikit atau berlebihan dapat terjadi penghambatan pertumbuhan.
Lingga P dan Marsono (2000) menyatakan bahwa nitrogen mendorong pertumbuhan yang cepat dengan perkembangan daun dan batang menjadi hijau dan besar, mendorong pertumbuhan vegetatif di atas tanah. Sutejo, M dan Mulyani (2002) menambahkan bahwa nitrogen didalam tanaman berperan sebagai sebuah konstituen protein, yang terdiri atas rantrai-rantai asam amino yang dihubungkan oleh rantai peptide. Protein adalah merupakan enzim-enzim yang amat penting dalam sel tanaman untuk proses metabolisme. Kekurangan unsur nitrogen memperlihatkan gejala tanaman menjadi kurus, laju pertumbuhan menurun, klorosis, daun berubah menjadi kuning hingga coklat akhirnya mati.

Sutejo (2002) menyatakan bahwa nitrogen diserap oleh akar dalam bentuk nitrat atau ammonium, akan tetapi nitrat ini segera tereduksi menjadi ammonium melalui enzim yang mengandung molybdenum. Apabila unsur nitrogen tersedia lebih banyak dari unsur lainnya, akan dapat dihasilkan protein lebih banyak. Semakin tinggi pemberian nitrogen semakin cepat pula sintesis karbohidrat yang diubah menjadi protein dan protoplasma. Pemberian zat $\mathrm{N}$ yang 
banyak pada tanaman penghasil daun akan sangat menguntungkan karena akan banyak menghasilkan daun dan batang.

Menurut Dwidjoseputro (1984), unsur $\mathrm{N}$ merupakan komponen penyusun dari senyawa esensial seperti asam amino dan juga terkandung dalam klorofil yang berfungsi dalam pembentukan pertumbuhan bagianbagian vegetatif tanaman, seperti batang, daun, dan akar.

Pertumbuhan merupakan hasil proses pembelahan, perpanjangan, dan diferensiasi sel. Ketiga proses tersebut membutuhkan energi yang diperoleh dari proses metabolisme yang terjadi dalam tubuh tanaman. Bila transfer energi dari satu sel ke sel yang lainnya berjalan dengan aktif maka pembelahan, perpanjangan, dan diferensiasi sel akan berlangsung dengan cepat, yang menyebabkan pertumbuhan tanaman juga semakin cepat.

\section{c. Pengaruh Interaksi Pupuk Kandang dan Urea}

Berdasarkan hasil sidik ragam pada taraf $5 \%$ terlihat bahwa perlakuan pupuk kandang dan urea berpengaruh nyata terhadap pertumbuhan mahoni pada parameter yang diamati yaitu panjang akar utama dan jumlah akar lateral, sedangkan pada parameter tinggi tanaman, diameter batang dan jumlah daun tidak berpengaruh nyata.

Kombinasi penggunaan pupuk kandang dan urea menunjukkan pengaruh nyata pada parameter panjang akar utama dan jumlah akar lateral hal ini diduga karena pupuk kandang dan urea yang diberikan telah mampu memenuhi kebutuhan tanaman mahoni akan unsur hara. Dalam hal ini kandungan unsur hara yang ada dalam pupuk kandang dilengkapi oleh pemberian urea, sehingga kedua pupuk tersebut saling melengkapi. Pupuk kimia mampu meningkatkan produktivitas tanah dalam waktu singkat, sedang pupuk organik merupakan pupuk alam dan melepaskan unsur hara secara perlahan-lahan sehingga mempunyai efek residu dalam tanah dan bermanfaat bagi tanaman berikutnya (Suprapto dan Aribawa, 2002).

Berbeda dengan parameter tinggi tanaman, diameter batang dan jumlah daun yang mana pemberian pupuk kandang dan urea secara kombeinasi menunjukkan berpengaruh tidak nyata. Dari hasil penelitian ini terlihat bahwa apabila pupuk kandang dan urea diberikan secara bersamaan atau 
kombinasi, maka pengaruhnya tidak terlihat, khususnya pada parameter tinggi tanaman, diameter batang dan jumlah daun mahoni. Tetap hanya bepengaruh pada parameter panjang akar utama dan jumlah akar lateral menunjukkan pengaruh yang nyata yaitu pada dosis pupuk kandang $\mathrm{k}_{3}$ dan urea $\mathrm{k}_{3}$.

Dalam hal ini dapat diartikan bahwa penggunaan dua jenis pupuk belum tentu dapat menunjang pertumbuhan tanaman secara menyeluruh karena setiap jenis pupuk memiliki persentase kandungan unsur hara yang berbeda serta cara kerja yang berbeda dalam proses penyediaan unsur hara bagi tanaman. Pemberian satu jenis pupuk belum tentu sebagai pelengkap bagi pupuk yang lain, sehingga dalam penelitian ini pemberian pupuk secara tunggal untuk parameter tinggi tanaman, diameter batang dan jumlah daun lebih baik jika dibandingkan secara kombinasi.

Berdasarkan data hasil penelitian, semakin tinggi pemberian dosis pupuk kandang yang dikombinasi dengan urea maka dapat meningkatkan jumlah akar utama dan panjang akar lateral. Dapat diartikan bahwa pemberian pupuk kandang dapat meningkatkan kesuburan tanah, terutama dalam hal memperbaiki sifat fisik, kimia dan biologi tanah, sehingga pada gilirannya akar dapat tumbuh dengan baik.

Brady (1990) dalam Junedi (2008) menyatakan bahwa penambahan bahan organik ke dalam tanah dapat menurunkan volume tanah karena bahan organik merangsang granulasi sehingga menimbulkan kondisi lepas dan sarang, dalam hal ini akar mahoni dapat dengan mudah berkembang. Utomo (1994) juga menyatakan bahwa nilai bobot volume tanah dipengaruhi oleh beberapa faktor, salah satunya adalah kandungan bahan organik tanah. Penambahan bahan organik (pupuk kandang) akan mengurangi kepadatan tanah. Menurut Hillel (1982) dalam Junedi (2008), kandungan bahan organik berkorelasi negatif dengan bobot volume tanah. Sutanto (2002) mengemukakan bahwa secara garis besar keuntungan yang diperoleh dengan memanfaatkan pupuk organik adalah mempengaruhi sifat fisik, kimia dan biologis tanah.

\section{KESIMPULAN}

1. Pemakaian dosis pupuk kandang dapat menigkatkan pertumbuhan tanaman mahoni secara nyata pada parameter tinggi tanaman dan 
jumlah akar lateral dengan dosis yang terbaik pada perlakuan $\mathrm{k}_{3}$.

2. Pemakaian berbagai dosis pupuk urea menunjukkan pengaruh tidak nyata dalam hal menigkatkan pertumbuhan tanaman mahoni pada semua parameter yang diamati.

3. Kombinasi pemberian pupuk kandang dan urea secara

\section{DAFTAR PUSTAKA}

Dwidjoseputro, 1984. Pengantar Fisiologi Tumbuhan. Gramedia. Jakarta.

Gardner, F. P., R. B. Pearce and R. L. Mitchell. 1991. Physiology of Crop Plants (Fisiologi Tanaman Budidaya, alih bahasa oleh Susilo). UI Press. Jakarta. 432p.

Hanafiah, K.A. 2003. Rancangan Percobaan Teori dan Aplikasi. Raja Grafindo Persada. Jakarta.

Junedi H, 2008. Pemanfaatan Kompos Jerami Padi dan Kapur Guna Memperbaiki Permeabilitas Tanah dan Hasil Kedelai Musim Tanam II. Prosiding Seminar Nasional Sains dan Teknologi-II 2008 Universitas Lampung, 17-18 November 2008. . [Internet, 15 Januari 2010].

Kastono, D. 1999. Budidaya Tanaman Semusim: Bagian Tembakau. Diktat Mata Kuliah Budidaya Tanaman Semusim. Fakultas Pertanian UGM. Yogyakarta.

Lindawati, N., Izhar dan H. Syafria. 2000. Pengaruh pemupukan nitrogen dan interval pemotongan terhadap bersamaan memberikan pengaruh tidak nyata terhadap parameter tinggi tanaman, diameter batang dan jumlah daun mahoni, tetapi pada parameter panjang akar utama dan jumlah akar lateral menunjukkan pengaruh yang nyata pada dosis pupuk kandang $\mathrm{k}_{3}$ dan urea $\mathrm{n}_{3}$.

produktivitas dan kualitas rumput lokal kumpai pada tanah podzolik merah kuning. JPPTP 2(2): 130133.

Lingga P. 1999. Petunjuk Penggunaan Pupuk. Penebar Swadaya. Jakarta Lingga $P$, dan Marsono. 2000. Petunjuk Penggunaan Pupuk. Edisi Revisi. Seri Agritekno. Penebar Swadaya. Jakarta.

Sutanto, R. 2002. Penerapan Pertanian Organik (Pemasyarakatan dan Pengembangannya). Kanisius Yogyakarta.

Sutanto, R. 2002. Pertanian organik. Kanisius. Yogyakarta.

Suprapto dan I.B. Aribawa. 2002. Pengaruh residu beberapa jenis pupuk organik terhadap pertumbuhan dan hasil bawang merah di lahan kering. Online (http://www. BPTP. Jatim deptan.go.id/templates/.

Sutejo, M. Mulyani. 2002. Pupuk dan Cara Pemupukan. Rineka Cipta. Jakarta.

Utomo, W.H. 1994. Erosi dan Konservasi Tanah. Universitas Brawijaya, Malang 